\title{
Tulane
}

Tulane Economics Working Paper Series

\section{Is Economics Useful for Public Policy?}

\author{
James Alm \\ Department of Economics \\ Tulane University \\ jalm@tulane.edu
}

Working Paper 1702

May 2017

\begin{abstract}
Economists have always played an important role in major public policy debates. Even so, I believe that the role of economists in these public policy discussions has often been misguided because it has typically relied upon "best practices", stated in the form of "general guidelines" or even "universal principles. However, "best practices" are not best if the specific situation does not conform with the assumptions that underlie the advice. So my first conclusion is a cautionary, and negative, one: Specific circumstances differ so profoundly across individuals, firms, markets, countries, and time that most any attempt to define "best practices" that apply in all circumstances will lead to profoundly misleading public policy recommendations. However, even if economics cannot identify "the" truth, it can often identify "a" truth. So my second conclusion is a more positive one: Economists should continue to develop multiple theories that inform public policies, but we should also focus our efforts on identifying and testing the critical assumptions that drive the results of these theories, recognizing that the validity of any assumptions will depend intimately on specific circumstances. I illustrate these two main conclusions with specific examples from my own work. I conclude with some "best practices" recommendations of my own, recognizing the obvious irony of such an effort.
\end{abstract}

Keywords: Public economics, public policy, best practices.

JEL codes: A1, B4, H8. 


\title{
Is Economics Useful for Public Policy?
}

\author{
James Alm ${ }^{1}$
}

\begin{abstract}
Economists have always played an important role in major public policy debates. Even so, I believe that the role of economists in these public policy discussions has often been misguided because it has typically relied upon "best practices", stated in the form of "general guidelines" or even "universal principles. However, "best practices" are not best if the specific situation does not conform with the assumptions that underlie the advice. So my first conclusion is a cautionary, and negative, one: Specific circumstances differ so profoundly across individuals, firms, markets, countries, and time that most any attempt to define "best practices" that apply in all circumstances will lead to profoundly misleading public policy recommendations. However, even if economics cannot identify "the" truth, it can often identify "a" truth. So my second conclusion is a more positive one: Economists should continue to develop multiple theories that inform public policies, but we should also focus our efforts on identifying and testing the critical assumptions that drive the results of these theories, recognizing that the validity of any assumptions will depend intimately on specific circumstances. I illustrate these two main conclusions with specific examples from my own work. I conclude with some "best practices" recommendations of my own, recognizing the obvious irony of such an effort.
\end{abstract}

The short answer is: Of course. However, there is a longer answer...

Economists have always played an important role in major public policy debates, in areas as diverse as the rationale for free trade, the financing of wars, the design of Social Security, the introduction of Medicare and Medicaid, the reform of welfare and other anti-poverty programs, minimum wage legislation, student loans, deficit reduction, and many more. There is virtually no significant public policy issue upon which economists have not advanced arguments, frequently on both sides. I have no doubt that the policy advice that economists have given has in many settings actually contributed to useful public policies.

Even so, I believe that the role of economists in these public policy discussions has often been misguided. Economists frequently resort in their public policy advice to "best practices", stated in the form of "general guidelines" or even "universal principles". Standard examples 
from surveys of economists in which upwards of 90 percent of respondents largely agree are "Rent controls reduce the quality and quantity of housing", "Free trade raises welfare", "Flexible exchange rates offer an effective international monetary arrangement", "Restricting U.S. employers from outsourcing work to foreign countries will not save U.S. jobs", and "Unless they have inside information, very few investors can make accurate predictions about whether the price of an individual stock will rise or fall on a given day". ${ }^{2}$ The so-called "Washington Consensus", a term coined by Williamson (1990), is a striking recent example.

In the narrower context of tax policy where I have spent my entire professional life, there are similar sweeping statements that command widespread support among economists: "A large federal deficit has an adverse effect on the economy", "Taxes on tobacco discourage smoking", "State and local government subsidies to professional sports franchises are inefficient", "The individual and the corporate income taxes should be integrated", and "Because of the 2009 economic stimulus, unemployment was lower at the end of 2010 than it would otherwise have been". ${ }^{3}$

Again, I have little doubt that these "best practices" have in many settings actually contributed to useful public policies. However, "best practices" are not best if the specific situation does not conform with the assumptions that underlie the advice. Indeed, I believe that we as economists have sometimes forgotten that policies that sometimes make sense do not always make sense. Relatedly, we often reduce the incredible diversity of individuals to a single, stereotypical identity, forgetting that policies that affect a "representative individual" in a welldefined way may well affect many other individuals in very different ways. When we forget these things, our "best practices" may in fact give wrong and misleading answers. 
This is not to deny that economists often disagree on many specific issues. It is also not to deny that economists in their professional writings often present their policy prescriptions with subtlety and sophistication, accompanied by appropriate qualifications, confidence intervals, and ranges. Nevertheless, many economists find it difficult to resist the temptation to give their public policy advice in easily digestible sound bites that are sweeping, universal, and certain. It may well be that many economists understand the unstated limitations of such statements. Even so, these pronouncements are frequently adopted by the public as "the" truth, rather than as "a" truth, and we seldom discourage this perception about our ability as economists to pronounce "the" truth to the masses.

And it is hard to resist political pressures to give such advice. An example, possibly apocryphal, of these pressures is illustrated by a quote from Lyndon Baines Johnson, who reportedly responded to an economics advisor who was giving a range of estimates about the impact of a policy by saying "Ranges are for cattle - give me a number". The more reliably documented quote from Harry Truman ("Give me a one-handed economist") also speaks to these pressures.

This type of "best practices" public policy advice certainly has some foundation, and there are clearly some good reasons for such general prescriptions. Just like we are told from an early age "Eat a good breakfast", "Don't swim after eating", or "Never drive on the railroad tracks", these pieces of homespun advice have some elements of truth. Even so, there are also reasons for skepticism about how meaningful, indeed how useful, such "best practices" may be in many specific situations. ${ }^{4}$

I am myself not immune from the temptation to give policy prescriptions in such a "best practices" mode. As I discuss in more detail later, I typically give "best practices" advice in a 
variety of settings in which I have done research, on policies ranging from tax incidence to tax enforcement to behavioral responses to tax reform and beyond. I could give additional examples from the work of others, but I prefer to cite my own work to demonstrate that I am not without sin myself.

So my first conclusion here is a cautionary, and negative, one: Specific circumstances differ so profoundly across individuals, firms, markets, countries, and time that most any attempt to define "best practices" that apply in all circumstances will lead to profoundly misleading public policy recommendations. The search for "a theory of everything", or a general scheme that specifies, for all possible settings, the details of a "best practices" tax policy is certain to fail. There are simply too many features that must be known but that are unknown and often unknowable, to implement any "best practices" prescriptions. These difficulties should not discourage the search for, say, specific policy guidelines that apply to a specific setting at a specific point in time. However, such guidelines will necessarily be couched in the specific circumstances under consideration, and they will be quite unlikely to apply in other settings. Rather, public policies must make intimate connection to the time and institutional settings in which they are employed. In other words, the search for "best practices" should be seen largely as a search for the "Holy Grail" - it is alluring and seductive but ultimately unachievable.

However, even if economics cannot identify "the" truth, it can often identify "a" truth, and the possibility of identifying "a" truth suggests the ways in which economists can play a useful role in public policy discussions. So my second conclusion is a more positive one. I believe that economics is most useful in one specific dimension: Economists should continue to develop multiple theories that inform public policies, but we should also focus our efforts on identifying and testing the critical assumptions that drive the results of these theories, 
recognizing that the validity of any assumptions will depend intimately on specific circumstances. In short, theory is essential in explaining the world. However, the world changes, and theories must also change. Theories that are based upon assumptions that capture the specific circumstances, institutions, even motivations facing individuals can help identify the effects of public policies in those particular settings, including the ways in which these effects depend upon the particular assumptions underlying the theory. It is no exaggeration to say that everyone has a "theory" that informs their thinking, even if it is not a well-articulated one, and economists have particular skills in developing - and testing - these theories. ${ }^{5}$ However, it is essential to remember that there is no such thing as a single theory that is universally applicable, in large part because the assumptions that underlie any theory are necessarily restrictive, applying in some settings and not in others. Instead, as economists we must remember that our theories are simply metaphors, meant to represent a specific situation and not meant to represent all situations, and certainly not meant to represent "the" truth. The ability to "choose wisely" among these myriad theories is what makes a good economist, at least one who can contribute usefully to public policy discussions.

In the following sections, I illustrate these two main conclusions with specific examples from my own work. I start with some of my own "best practices" advice, and then I illustrate the specific ways in which the underlying assumptions of this advice have gone astray. I conclude with some "best practices" recommendations of my own, recognizing the obvious irony of such an effort.

\section{(1) "An individual income tax with graduated rates has a progressive pattern of tax incidence."}


There is certainly a strong element of truth to this policy conclusion, as demonstrated in the thousands of tax incidence studies that have been conducted in the United States and elsewhere over even the last half century, of which the still-classic examples remain Pechman and Okner (1974) and Pechman (1985). My own tax incidence work with colleagues like Roy Bahl, Fitzroy Lee, Yongzheng Liu, Jorge Martinez-Vazquez, Matt Murray, Jim Richardson, Edward Sennoga, Steve Sheffrin, Dave Sjoquist, and Sally Wallace, in the U.S. and abroad, has typically generated this conclusion. ${ }^{1}$

However, there are many assumptions that underlie this result. The most obvious is the implicit assumption that all income is in fact subject to taxation. This assumption is clearly wrong, at least in many settings where legal tax avoidance and illegal tax evasion are prevalent. ${ }^{6}$

For example, in work conducted in the 1980s in Jamaica with Roy Bahl and Matthew Murray, we found that the individual income tax in Jamaica had a highly progressive statutory tax incidence, reflective of a steeply progressive marginal tax rate structure that imposed rates that increased from 30 percent to 57.5 percent at that time, a result that is consistent with the “best practices” advice. More precisely, we (Alm, Bahl, and Murray, 1991) estimated that taxes paid as a percentage of "taxable income" (or income in the income tax base) increased steadily from 7 percent on the lowest income category to 44 percent on the highest income category. However, we also estimated enormous amounts of legal tax avoidance (via tax credits, fringe benefits, and overtime income) and illegal tax evasion (via non-filing and underreporting). When we recalculated taxes paid relative to "comprehensive income" (or total income, including taxable income but adding avoidance income plus evasion income), we found that the average tax rate rose slightly over the lower income classes, before falling substantially at higher income classes. I have found similar results on the incidence of payroll taxes in Jamaica: the existence of

\footnotetext{
${ }^{1}$ For example, see Alm, Lee, and Wallace (2005), Alm (2006), and Alm and Wallace (2007).
} 
large amounts of tax avoidance and tax evasion turned the pattern of tax incidence from highly progressive to moderately regressive (Alm, 1988). Even in the U.S., with far lower levels of avoidance and evasion, there is work by Johns and Slemrod (2010) that shows that the "true" incidence of taxation differs from its "statutory" incidence.

\section{(2) “A sales tax has a regressive pattern of tax incidence."}

Studies on the incidence of sales tax using a similar methodology typically conclude that general sales taxes (or consumption taxes more broadly) lead to a regressive pattern of tax incidence. This conclusion stems from the empirical observation in many settings that consumption as a percentage of (annual) income declines with income, so that a tax on consumption will disproportionately burden lower income households. This conclusion shapes the views of many people on what would happen if the sales tax was expanded to include services: the expansion would (many conclude) make the sales tax even more regressive.

However, although overall consumption declines as a percentage of income with income, this does not mean that we can similarly assume that consumption of specific items exhibits the same pattern. Just because households with lower levels of income tend to devote a higher percentage of their income to overall consumption, this does not mean that the same pattern of consumption applies to specific consumption items like services.

In fact, this assumption about specific consumption patterns of services is not necessarily the case, depending upon the specific services that will be taxed and the specific patterns of service consumption. As part of a recent tax reform study in Louisiana, Grant Driessen and I examined the incidence of expanding the Louisiana state sales tax to a range of personal and other services. ${ }^{7}$ Using information on consumption patterns from the Consumer Expenditure 
Survey, we (Alm and Driessen, 2016) found that taxing services actually decreased, and decreased substantially, the regressivity of tax burdens, because consumption of taxed services increased steadily (if somewhat erratically) with income, unlike general consumption patterns. Johnson and Sheffrin (2015) found a similar surprising result if the Louisiana sales tax base was expanded to include food. Because benefits to low income household under the Supplemental Nutritional Assistance Program (SNAP) are largely untaxed for the vast majority of low income households, the taxation of food in a general sales tax has no impact on their sales tax burdens. In fact, Johnson and Sheffrin (2016) concluded that taxing food in Louisiana actually decreased the regressivity of sales tax burdens.

\section{(3) "The U.S. individual income tax imposes a 'marriage tax' on couples with similar earnings, and gives a 'marriage subsidv' to couples with different earnings."}

Many couples in the U.S. pay higher taxes when married than their combined tax liabilities as single filers (a so-called "marriage tax" or "marriage penalty"), while many other couples receive a subsidy or bonus because their joint taxes fall with marriage. This lack of "marriage neutrality" in the income tax strikes most people as an unjustifiable feature of the tax and transfer system, and many policy debates over the years have centered on its elimination. These income tax consequences from marriage are created by two basic conditions in the individual income tax and its associated programs: basing the tax on household (not individual) income, and imposing the tax at different (not constant) marginal tax rates at different levels of income (Bittker, 1976; Bakija and Steuerle, 1991; Congressional Budget Office, 1997).

There have been numerous attempts over the years to measure the marriage tax. My own work with Leslie Whittington and Stacy Dickert-Conlin documented clear evidence of a sizeable marriage tax for many couples, as well as a significant marriage bonus for many other couples, at 
least up until the mid-1990s (Alm, Dickert-Conlin, and Whittington, 1999). In particular, couples with similar incomes nearly always paid a marriage penalty; couples with only a single earner nearly always received a marriage bonus. In other work with Leslie Whittington and Lee Badgett, we extended these calculations to examine the income tax consequences of legalizing same-sex marriages, given that the empirical evidence at the time (2000) indicated that same-sex couples tended to have similar incomes and so would face a marriage tax (Alm, Badgett, and Whittington, 2000). In fact, our calculations confirmed the existence of a significant marriage tax for same-sex couples if same-sex marriage was legalized, thereby validating the common perception of the income tax.

However, these results depended upon the specific features of individual income tax structure that existed from the 1960s through the 1990s (e.g., tax rates structures, deductions, exemptions, and the like), as well as with the specific income patterns for individuals and couples during this period. If these assumptions change, the results on the magnitude and even the existence of marriage tax should change as well.

In more recent work with Sebastian Leguizamon, we updated these estimates using both more recent data and better individual data from the Current Population Survey. Our (Alm and Leguizamon, 2015) updated results now demonstrate that the 2009 individual income tax is still far from marriage neutral. However, we also show that most couples now receive on average a large marriage bonus regardless of relative earnings of the couples. Indeed, the percentage of families facing a marriage tax has fallen significantly in recent years, while the percentage receiving a subsidy has risen over this same period. Other work with Sebastian Leguizamon and Susane Leguizamon using 2010 data from the American Community Survey further finds that the income tax impacts of legalizing same-sex marriage have now become very small (Alm, 
Leguizamon, and Leguizamon, 2014), unlike my earlier estimates (Alm, Badgett, and Whittington, 2000).

Again, these differences reflect the significant changes in the federal (and state) income tax systems in recent years, changes that seem not yet to have filtered into policy discussions. The implicit assumptions about the structure of the U.S. individual income tax and its tax treatment of the family have changed significantly, due largely to the Bush tax cuts of the early 2000s, and most analyses of the marriage tax have failed to grasp these changes.

\section{(4) “A tax that achieves vertical equity is 'fair'."}

"Fairness" in tax policy means both vertical and horizontal equity. "Vertical equity" refers to how the tax burden changes as income changes, and generally suggests that the tax should reflect a taxpayer's "ability to pay". "Horizontal equity" refers to how like individuals (or "equals) are treated, and requires that equally situated taxpayers pay the same level of tax. While there is little debate regarding the justification for vertical equity as an important consideration in tax policy (Sheffrin, 2013), horizontal equity as a fundamental principle of tax policy has been questioned by some (Kaplow, 1989). Even so, many analysts recognize that equal treatment of equals is compelling as a practical principle of tax policy.

However, most analyses of the distributional effects of taxation focus largely on vertical equity, giving scant attention to horizontal equity. These analyses typically conclude that a progressive pattern of tax incidence, in and of itself, demonstrates a "fair" tax system. However, in so doing they also typically ignore the horizontal equity of the tax system. The implicit assumption seems to be that households with similar income are largely the same, so that horizontal equity is effectively achieved if a progressive pattern of tax incidence is found. 
However, this assumption need not hold. In work with Sally Wallace on another tax reform project in Jamaica, we (Alm and Wallace, 2007) calculated under standard incidence assumptions that the overall distribution of Jamaican income tax burdens in the early 2000s was markedly progressive (at least when measured relative to taxable income), with average tax rates that rose steadily from 0 percent on the lowest income groups to over 23 percent on the top groups. However, we also found enormous variation in the average tax rates within income groups. For example, we calculated that the minimum versus maximum average tax rate in various narrowly defined income classes varied by as much as 18 percentage points, with correspondingly large coefficients of variation of the average tax rates. Bird and Miller (1989) find similar results for indirect taxes on low-income Jamaican households, given the wide variation in consumption patterns even within similar income levels.

These results do not deny the importance of vertical equity in the assessment of tax fairness. However, they do suggest that vertical equity is an incomplete guide to fairness, in large part because households that have equal income typically are very different from one another in other features that affect their tax liabilities.

\section{(5) “To increase tax compliance, increase enforcement."}

The classic Allingham and Sandmo (1972) model of tax compliance is based on the assumption that an individual views tax compliance as a gamble, weighing the expected benefits of successful cheating against the risky prospect of detection and punishment. The standard conclusion from this analysis is that an individual pays taxes because of the fear of being caught and penalized, and standard comparative statics analysis of this simple model demonstrates that an increase in the audit rate (or in the penalty rate on detected evasion) will increase reported 
income. ${ }^{8}$ Empirical evidence also is largely consistent with the "best practices" policy advice that greater enforcement (e.g., greater audit rates, larger fine rates) will improve compliance. My own empirical estimates of the reported income-audit rate elasticity derived from laboratory experiments (mainly with Michael McKee and Betty Jackson) and from field data (with Roy Bahl, Matthew Murray, Mohammad Yunus, Jeremy Clark, and Kara Leibel) have consistently found a significant positive elasticity, often between 0.2 and 0.4 and occasionally larger. ${ }^{9}$

However, there are numerous reasons for some caution in using this policy prescription in all settings; that is, the implicit assumptions underlying this "best practices" advice may not always hold.

First, the underlying assumptions in the Allingham and Sandmo (1972) are that individuals are purely rational, that they have unlimited will-power, and that they are motivated entirely by narrowly defined and individually based financial considerations. All of these assumptions have been increasingly questioned under the general rubric of "behavioral economics".

Indeed, in models informed by alternative behavioral economics considerations, the clear-cut comparative statics response to higher audit rates becomes weaker. Further, these alternative models assume an array of other plausible motivations for "why people pay taxes". Individuals may be motivated by the way in which the compliance decision is "framed" (e.g., as a loss versus a gain), they may misperceive the true costs of their actions (e.g., overweighting or underweighting of audit rates), and they may have difficulty making all of the computations due to complexity or uncertainty. Individuals may also be motivated by a wide range of factors, including self-interest (narrowly defined) but also by notions of fairness, altruism, reciprocity, empathy, sympathy, trust, guilt, shame, morality, alienation, patriotism, social customs, social 
norms, tax morale, intrinsic motivation, and many other objectives that often have their origin in group considerations. All of these alternative motivations reduce the potential impact of audit rates, and they may even reverse their effect, if more audits crowd out the intrinsic motivation to pay taxes. $^{10}$

Second, and perhaps of more relevance, the empirical evidence is considerably more problematic than it appears. My own empirical evidence with either field data or laboratory experiments suggests that more audits increase compliance, but the reported income-audit rate elasticity is small and varies across studies. Also, this work often finds that more audits increase compliance but in a non-linear way, so that the deterrent effect diminishes with higher audit rates. My controlled field experiments in Colombia with Carlos Ortiz and Diana Rocha have found that telling individuals that they will be subject to "more scrutiny" via a message from the tax authority has a positive impact on compliance, even if small, variable, and fleeting (Alm, Ortiz, and Rocha, 2016). However, there are also other field studies with these messages that find no impact, and sometimes even a conflicting impact, on compliance (Slemrod, Blumenthal, and Christian, 2000; Hallsworth, 2014).

Of some special relevance, my laboratory experiments with Michael McKee clearly demonstrate enormous variation in individual responses to increased audit rates. In a large set of experiments with an identical experimental design, we varied the random audit rate from 5 percent, to 10 percent, to 30 percent, and to 40 percent, in various combinations of increases and decreases, holding constant all other factors that may affect decisions (e.g., tax rates, penalty rates, public goods). Our overall reported income-audit rate elasticity is roughly in the 0.2 to 0.4 range. However, we also find that this overall response is driven largely by only about $1 / 3$ of the subjects who respond to a higher audit rate by reporting more income; indeed, estimating the 
reported income-audit rate elasticity with only these subjects generated an elasticity well in excess of unity, compared to the lower estimated elasticity of 0.2 to 0.4 when all observations were included. Further, roughly $1 / 2$ of all subjects reported about the same level of income when the audit rate changed, and as much as 1/6 of the subjects actually reported lower income when audit rates increased! Keep in mind that these results were generated in a controlled setting in which the only causal factor that varied was the audit rate. The "average treatment effect" (ATE) clearly demonstrates the standard and expected individual response, but the ATE is not the only, or even the most interesting, measure of responsiveness.

All of this evidence convinces me that there is certainly some truth to the Allingham and Sandmo (1972) model of compliance, but that its reliance on standard assumptions limits its relevance in many settings. In particular, this evidence suggests to me that, although many individuals may well be motivated by narrowly defined and individually based financial considerations, there are many other individuals who are influenced by non-financial considerations (e.g., empathy, sympathy, guilt, shame).There are also many other individuals who are influenced by social considerations. In short, there is great heterogeneity across individuals: individuals cannot be represented by a single representative and stereotypical agent whose behavior is assumed to follow the standard homo economicus model of behavior. My work on firm tax evasion with Jorge Martinez-Vazquez and Chandler McClelland finds similar results for firms, and my work with Jay Shimshack on environmental compliance also comes to similar conclusions. ${ }^{11}$

\section{(6) “Better information will improve tax compliance."}


A similar policy recommendation that emerges from much of the compliance literature is on the role of information: more information will improve tax compliance. There is in fact much evidence to support this recommendation, as most clearly demonstrated by U.S. Internal Revenue Service (IRS) research. ${ }^{12}$

In recent years, computers have opened the doors to information storage and utilization the likes of which are historically unparalleled. Computers can readily save large stocks of information, and they can comb through such information at lightning speed. This has resulted in an unparalleled access to information. In particular, information storage, information retrieval, and information transmission have proven pivotal in ensuring compliance in vast segments of the nation's economy. Over the last several decades, Congress has put technology to use, requiring third-party tax information reporting throughout the economy. Employers must issue Form W-2, in which wage income is reported to the IRS and all employees. Banks and brokerage firms must issue Forms 1099-INT and 1099-DIV to investors, reporting interest and dividend income. Businesses must issue Form 1099-MISC to independent contractors, reporting payments for services rendered. The failure to prepare and timely submit these tax information returns is subject to penalties that have become increasingly onerous.

This third-party tax information reporting expansion has had a remarkable impact on tax compliance. As noted earlier, empirical evidence from the IRS strongly supports the virtues of third-party tax information reporting: when third-party tax information return reporting is present (particularly when coupled with withholding), tax compliance is high. The converse is also true: in the absence of third-party tax information return reporting, tax compliance plummets. ${ }^{13}$ 
It is therefore clear that the information available to the tax authorities (especially on income sources) is an essential component of a tax compliance strategy. However, the evidence on the information available to taxpayers may have different impacts.

For example, my laboratory experiments with Betty Jackson and Michael McKee show clearly that knowing that audit rates have increased improves compliance; not surprisingly, higher audit rates have no impact on individual compliance if individuals do not receive this "official" information (Alm, Jackson, and McKee, 2009). We also have additional work that demonstrates that knowing how your tax dollars are used improves compliance, especially if individuals are involved in the decisions (Alm, Jackson, and McKee, 1993). However, in other laboratory experiments with Kim Bloomquist and Michael McKee, we find that knowing what your "neighbors" are doing can affect your compliance in adverse ways: if you find that your neighbors are complying, then you will tend to comply as well, but if you find that your neighbors are cheating, then you will respond by cheating more yourself (Alm, Bloomquist, and McKee, 2016). Still other laboratory experiments with David Bruner and Michael McKee examine the nature of an individual revelation of information to other individuals. We (Alm, Bruner, and McKee, 2016) find that most individuals send accurate messages about their own audit outcomes and their own compliance behaviors. Nevertheless, we also find that many individuals are systematically dishonest about being audited, claiming that they were audited when they were not, and we observe that individuals who engaged in tax evasion and who were audited were more truthful in their communications than those whose tax evasion went undetected.

These quite diverse results demonstrate that information per se is a mixed tool, with impacts on compliance that depend entirely on how the information is provided and what the 
information contains; that is, the assumptions that underlie the informational content drive the ways in which information affects compliance.

\section{(7) “To increase economic growth, cut tax rates."}

In the attempt to increase economic growth, many economists advocate a "best practices" policy of cutting tax rates. There are in fact compelling reasons for this policy prescription. There is much empirical evidence - sometimes conflicting - that lower taxes encourage work effort, they increase the return to savings and investment, they encourage the creation of new firms and new jobs, they increase investment, they boost labor and capital mobility, and the like, all of which should contribute to higher economic growth. ${ }^{14}$

The empirical literature on the effects of taxes on economic growth is enormous, with numerous studies producing a wide variety of results and only modest consistency. ${ }^{15}$ Despite this lack of consensus, it is easy to find economists like Arthur Laffer recommending tax cuts to spur economic growth, and it is even easier to find politicians promising to cut taxes to stimulate growth. ${ }^{16}$ The most recent poster child for this state-level policy prescription is Kansas Governor Sam Brownback, and the still emerging policy prescriptions at the national level also seem consistent with this supply-side policy.

My own work on the growth effects of taxes (and other government policies) on state economic growth demonstrates that there are in fact some circumstances under which state tax cuts have increased state economic growth. In work with Janet Rogers using annual state (and local) data for the years 1947 to 1997 for the 48 contiguous states, we (Alm and Rogers, 2011) estimated the effects of a large number of factors, including taxation and expenditure policies, on state economic growth. We found that the correlation between state (and state and local) taxation 
policies was often statistically significant, with the expected result that lower taxes increased state economic growth. However, we also found that the impact of taxes on growth was quite sensitive to the specific regressor set and time period, and often in an unexpected direction. For example, the impact of total state taxes on economic growth was wildly variable; the results for the components of taxation (e.g., individual income taxes, corporate income taxes, sales taxes) were slightly more consistent, but these results often indicated a surprising positive (though often statistically insignificant) impact of higher taxes on growth. Results for expenditures were considerably more consistent than the tax results, but again in an unexpected direction. In almost all cases, expenditures were negatively and significantly correlated with growth in per capita income, even spending that augmented state infrastructure.

Of some interest, the only consistent result that we found was for a state's political orientation, which had consistent and measurable effects on economic growth. Surprisingly, however, we found that a more "conservative" political orientation was associated with lower rates of economic growth.

In some more recent empirical work with Bibek Adhikari, we examined the impact of flat rate tax reforms in former Russian states on post-reform economic growth. We (Adhikari and Alm, 2016) used "synthetic control" methods to examine the economic performance of eight Eastern and Central European countries that adopted flat tax systems between 1994 and 2005 (Estonia, Latvia, Russia, Slovak Republic, Ukraine, Georgia, Romania, and Turkmenistan), comparing the post-reform GDP per capita of these "treated" countries with a weighted average of similar but "untreated" (or non-reform) countries. We found positive impacts in all 8 countries, with 7 out of 8 cases significant at the conventional level, and these results were robust to a wide range of sensitivity tests. Even so, we found very different growth impacts in some countries 
than in others, due largely to the timing of reform (e.g., first-wave versus second-wave reform countries) and to other reforms that were introduced at the same time (e.g., financial, legal, or political reforms).

These conflicting results indicate that a one-size-fits-all strategy of tax cuts does not have uniform impacts on economic growth, as assumed by tax-cut advocates. Rather, the effects depend upon specific circumstances: what taxes are cut, what is the current environment, what are neighboring governments doing, what other reforms are introduced, and the like. Recent work by Gale, Krupkin, and Rueben (2015) finds similar results for more recent years.

\section{(8) “The 'Great Recession' imposed significant fiscal burdens on state governments.”}

The "Great Recession" lasted from December 2007 to June 2009, and it wreaked havoc on the revenues of the "average" state government. According to data from The Nelson A. Rockefeller Institute of Government, between 2007 and 2010 own source revenue for the 50 state governments in total declined by 3.43 percent, and 32 states experienced decreases in own source revenue; similarly, between 2008 and 2010 own source revenues for all 50 state governments declined by 7.32 percent, and 45 states experienced decreases in own source revenue. ${ }^{17}$ Other data paint a comparable and bleak picture for state government finances.

However, the notion that all state governments were similarly affected is simply false. In work with David Sjoquist, we examined state government revenues several years after the end of the Great Recession to measure how different states have - or have not - recovered in the aftermath of the Great Recession, and we (Alm and Sjoquist, 2014) also attempted to explain why these different patterns of recovery emerged. We used data from the U.S. Census Bureau on state government own source revenue (OSR), for the years 2007 through 2012 for state 
governments, and we combined these data with various economic, demographic, and political data. To measure "revenue recovery", we compared OSR in 2012 for state governments with that in 2007 (the last year before the recession hit).

Overall, we found that by 2012 many state governments had in fact recovered the revenue they lost during the Great Recession, even though there were some that had not. For example, the ratio of state government OSR in 2012 to OSR in 2007 shows that most (42) states had OSR 2012 greater than 2007 OSR. To the extent that populations have either changed, a better measure is per capita OSR in 2012 to the same for 2007. By this alternative measure, 31 states had recovered the lost revenue by 2012. One last measure is real OSR per capita, calculated as real OSR per capita for 2012 divided by the same measure in 2007 and using the consumer price index to measure inflation. By this measure, only 6 states had fully recovered from the Great Recession. We also found that there is no single causal explanation for recovery that applies to all state governments.

In short, the underlying assumptions that all states were the same and that all states were equally affected by the economic shocks of the Great Recession and recovered in similar ways were was wrong.

\section{(9) “The collapse of housing prices imposed significant fiscal burdens on local governments, given their reliance on property taxes."}

A similar policy prescription applies to local governments. The bursting of the housing bubble and the resulting decline in economic activity should, it is widely claimed, had a serious negative impact on local governments, given their dependence on local property taxes as a major source of revenues. Again, this claim is based on the assumptions that local governments are 
equally reliant on the property tax, that these property tax systems operate in similar way, and that all local governments are the same. All of these assumptions are misinformed.

Now it is of course true that there are several channels by which changes in housing values driven by changes in economic activity may affect local government tax revenues (Lutz, Molloy, and Shan, 2011). The most obvious is via the property tax, although this link is neither immediate nor automatic, given the way that property taxes depend upon assessments. Other channels are more closely linked to economic activity. Real estate transfer taxes depend upon the volume and the value of real estate transactions, although these taxes are of relatively little importance. Less direct channels include those affected by declines in housing values. For example, a decline in housing values may depress new housing construction, thereby reducing sales tax revenues generated by the materials used in construction. The decline in home construction and the resulting fall in employment may also reduce income taxes. Finally, a decline in housing values may reduce consumer expenditures (and so sales tax revenues) via wealth effects. All of these channels no doubt formed the basis for the "best practices" policy prescription on the impact of housing prices on local governments.

However, the validity of these channels in general does not mean that they have equal effects on all local governments. In work with Robert Buschman and David Sjoquist, we used data from the U.S. Census Bureau to examine the trends of local government revenues (especially the property tax) over the last years before and after the Great Recession. We (Alm, Buschman, and Sjoquist, 2011) found that there is great diversity in the experiences of local governments over this period and especially in the immediate past several years. In particular, we found that the widespread expectation that most local governments suffered the same fiscal fate as state governments is not generally supported, at least to date. We concluded that local 
government reliance on the property tax rather than more elastic revenues sources like income, sales, and excise taxes may in fact have been a significant advantage for local governments in the current economic situation.

More precisely, we find that overall collections of local property taxes actually rose steadily over the period 1998 to 2009 , roughly doubling over this period. The annual percentage change in local collections always exceeded 4 percent, and was often been even greater; it is especially striking that even in the last two years of this period the growth rate was been greater than 4 percent. Real per capita collections also rose from $\$ 1000$ per capita in 1998 to nearly $\$ 1400$ per capita in 2009. However, these national trends hide enormous state variation. Looking at the weighted growth rates of property taxes for the individual periods 2006-2007, 2007-2008, and 2008-2009, as well as over the entire 2006-2009 period, we found that even in the most recent period (2008-2009), well over half of the states experienced a growth in property tax revenues. Those states that suffered a loss in revenues tended to be concentrated in the Southeast and somewhat erratically in the Midwest and the Northeast. For the entire 2006-2009 period, only 12 states experienced a decline in revenues (Idaho, North Dakota, Texas, Michigan, Indiana, Ohio, Kentucky, Tennessee, South Carolina, Florida, Pennsylvania, and Maine).

In short, we found that substantial numbers of local governments largely avoided the significant and negative budgetary impacts seen most clearly for state and federal governments, despite the claims of policy analysts to the contrary. The implicit assumptions that governments were the same and that they would be equally affected by the economic forces of the Great Recession were - once again - wrong.

\section{(10) "Tax reform should broaden the tax base to allow lower (and uniform) tax rates."}


The standard, nearly universal, advice for tax reforms is the mantra of a "broad base, low rate" reform (or "BBLR"), often referred to as the Schanz-Haig-Simons view of income taxation. ${ }^{18}$ Indeed, when people think of "tax reform", the vision that most often comes to mind is the 1986 U.S. federal tax reform, the Tax Reform Act of 1986, which closely followed this "best practices" advice. I myself have invoked this basic policy advice on nearly all of the tax reforms upon which I have worked, in such diverse places as Jamaica, Egypt, Turkey, China, Pakistan, Tunisia, Colombia, Puerto Rico, Ukraine, and (most recently) Louisiana.

There are sound reasons for these guidelines. A broader tax base can generate higher levels of revenues for given tax rates, if desired; a broader tax base can instead raise the same revenues with lower tax rates. A broader base that, say, treats all forms of income equally helps achieve both horizontal equity and vertical equity, since individuals with the same level of "comprehensive income" are treated equally and individuals with greater comprehensive income likely pay more in taxes. A broader tax base that taxes all forms of activities at the same rate does not create incentives for individuals and firms to shift activities from higher tax to lower tax regimes, thereby lowering excess burdens. Lower tax rates also reduce efficiency costs given that excess burdens increase (and so decrease) with the square of the tax rate. For these (and other) reasons, nearly all tax reforms follow the BBLR guidelines. Many reforms also add the additional guideline of a "uniform tax rate", largely for administrative reasons.

However, these policy prescriptions largely ignore the many ways in which "optimal" real-world tax policy diverges from the BBLR guidelines, largely because real-world tax systems differ markedly from those assumed by proponents. On efficiency grounds, we often diverge from the BBLR guidelines by excluding a specific tax base that theory suggests should be taxed because we believe that it may be costly to tax (e.g., imputed rental income, unrealized capital 
gains, in-kind income), because we want to increase its use due to its possible social benefits (e.g., charitable donations, homeownership), or because we want to encourage economic growth (e.g., tax incentives). We also tax some activities at higher (or lower) rates than other activities, again for efficiency reasons, because efficient taxes require higher rates on less responsive activities, higher (lower) tax rates on activities that generate negative (positive) externalities, low (perhaps zero) tax rates on capital income (including capital gains), and even negative tax rates on gifts and bequests. Indeed, there are compelling efficiency reasons for diverging from broad bases and uniform tax rates. ${ }^{19}$

There are similarly compelling equity reasons for diverging from the BBLR guidelines. The selective use of deductions, exemptions, and credits allows tax liabilities to be adjusted more precisely to individual circumstances, reducing the tax liabilities of individuals and families with more dependents, higher medical costs, or heavier state (and local) taxes, or of taxpayers who are older, blind, or disabled. Indeed, a tax base that diverges in significant ways from a broad base may offer a greater opportunity to impose a more progressive tax rate structure. Also, progressive tax rates allow tax liabilities to reflect more precisely vertical equity considerations by imposing higher (lower) tax rates on those with greater (lower) ability to pay.

Of course, political considerations no doubt enter the calculus of politicians in deciding to diverge from the BBLR guidelines.

My own recommendations on tax reforms in the many places in which I have worked reflect these tensions. Indeed, my recent work with James Richardson and Steven Sheffrin on the Louisiana tax system illustrates these divergences between the BBLR mandate and the specific reforms that we recommend. We recommended expansion of the sales tax base to include somebut not all - services, the expansion of the individual income tax base to include some - but not 
all - deductions and other tax preferences, and the elimination of several - but not all - of the development incentives in the corporate income tax base, and a largely flat rate tax structure but with some progressivity. ${ }^{20}$

In many respects, the BBLR approach implicitly assumes that there is a single, representative taxpayer. If taxpayers are essentially all alike, then there is no reason for the tax system to treat them differently via tax preferences that adjust the tax base or via tax rates that vary with the base. In fact, however, individuals and households differ markedly in multiple dimensions. Given this diversity, real-world tax systems diverge in many ways from the perspective that motivates, and justifies, the BBLR approach.

All of these considerations suggest that a broad-base, low-rate approach may sometimes be the appropriate path for tax reform. However, it may also be proper to diverge in significant ways from the BBLR guidelines, depending of course on specific circumstances. ${ }^{21}$

I hesitate to bring others into my discussion, but a recent exchange nicely illustrates the conflicting conclusions that the very best experts can draw about an optimal tax system and optimal tax reform. Mankiw, Weinzierl, and Yagan (2009) concluded that:

- The optimal marginal tax schedule could decline at high incomes.

- A flat tax, with a universal lump-sum transfer, could be close to optimal.

- Capital income ought to be untaxed.

In sharp contrast, Diamond and Saez (2011) concluded, in these exact same dimensions, that:

- Very high earnings should be subject to rising marginal rates and higher rates than current U.S. policy for top earners.

- Tax and transfer policy toward low earners should include subsidization of earnings and should phase out the subsidization at a relatively high rate.

- Capital income should be taxed.

There are profound differences here, even among economists who are looking at the exact same evidence but who are drawing completely opposite conclusions. These conflicting conclusions 
are in large part because underlying assumptions and evidence about what is driving these theories and the resulting recommendations differ (and perhaps also because underlying value judgments also differ).

\section{General Lessons: Is Economics Useful for Public Policy?}

In essence, my basic message is that those of us who wish to inform public policy discussions should continue to do so, but that we should also exhibit some modesty in our proclamations. Specifically, and to repeat the two basic conclusions with which I began, I believe that we should not attempt to identify simple one-line, media-friendly "best practices" policy advice. Rather, I believe that we should develop and test and continually update theories that inform public policies in specific settings, focusing our efforts on identifying the critical assumptions that drive the results of our theories and recognizing that the validity of any assumptions will depend intimately on specific circumstances. This message is in the spirit of other policy advice given by far more accomplished economists than me, such as Charles Manski on public policy under uncertainty, James Heckman on the external validity of policy innovations, Dani Rodrik on the value of economic models, Ariel Rubenstein on "economics fables", and Paul Krugman on "policy entrepreneurs". Of special relevance is the work of Alexander Gerschenkron on European economic development, who warned that simple application of economic principles across all times and all countries could be decidedly misleading. Recent critiques of the "Washington consensus" make this warning especially timely.

In this regard, Stephen Jay Gould has emphasized that it is grossly misleading to represent a complex system by a single, so-called representative agent, who behaves in some average or stereo-typical way. Instead, most systems have incredible variety - a "full house" of 
individual behaviors - and the proper understanding of any system requires recognition of this basic fact. Indeed, Gould (1996) argued that the way in which a system changes over time - or by analogy the way in which a system responds to policy initiatives - is attributable largely to changes in the amount of variation within the system, rather than to changes in some largely meaningless "average" behavior (or ATE) across its individual members.

This lesson is, I believe, especially apt for public policy prescriptions. People exhibit a remarkable diversity in their behavior. To return to the specific issue of tax compliance, there are individuals who always cheat and those who always comply, some who behave as if they maximize the expected utility of the tax evasion gamble, others who seem to overweight low probabilities, individuals who respond in different ways to changes in their tax burden, some who are at times cooperative and at other times free-riders, and many who are influenced by the social context in which decisions are made and who are motivated by notions of fairness, altruism, reciprocity, trust, social norms, guild, shame, and morality. Public policies toward tax compliance must address this "full house" of behaviors in devising policies to ensure compliance. And public policies more broadly must recognize this "full house" of behaviors in devising policy.

Without irony, I finish with my own "best practices" for economists who hope to inform public policies.

First, economists need a "full house" of theories to explain the "full house" of behaviors. These theories should build upon mainstream economics approaches, but they also should not be limited by the standard economics paradigm. Instead, these new theories should utilize the insights of other disciplines, such as psychology (e.g., behavioral economics) and also sociology, anthropology, and other social sciences in order to understand better those features of naturally 
occurring settings that are likely to affect individual and group decisions. Using alternative perspectives on human behavior cannot help but expand our understanding of individual and group behavior, as demonstrated most clearly in Akerlof and Kranton (2010).

Second, economists must be explicit about the assumptions that underlie their theories because it is these assumptions that drive the conclusions. For example, are individuals motivated by self-interest? Are they motivated by non-financial considerations? How do group and other social considerations influence behavior? Are markets competitive? Is information perfect? These assumptions drive the theoretical results - and so the policy prescriptions that the theory generates.

And third, as my own examples from my own mistaken policy advice clearly demonstrate, economists must continually test the underlying assumptions of their theories - including of course whether the theoretical assumptions match with the empirical reality. Whether all of these assumptions actually apply in specific settings will require empirical strategies of some sophistication, including strategies that address both identification of causal effects (e.g., internal validity) and generalization of specific results to other settings (e.g., external validity). These strategies should also include the necessity of replication, something for which our profession often has few incentives. Finally, these strategies should take advantage of empirical work that uses administrative data of the most up-to-date vintage. All of these empirical strategies are essential in determining whether one's policy prescriptions may actually apply. For example, my various examples illustrate that "best practices" advice often is based on theoretical assumptions that apply in some settings but not others, it is often derived from empirical analysis that uses old and outdated data that no longer are relevant, and it often attempts to reduce responses to an 
average treatment effect that ignores the enormous diversities of behavior. All of these diminish the ability of "best practices" to inform usefully public policy.

However, my own examples also illustrate that useful public policy advice can emerge, once the complexity of the real-world is recognized and acknowledged. Indeed, I do not believe that we as economists should shy away from giving policy advice. I firmly believe that the advice that emerges from careful analysis can inform policy, not because this advice is necessarily perfect but because it is often far better than what would otherwise be used. I simply suggest that any policy advice must emerge from an analysis that recognizes context and time. After all, "this is the business we have chosen".

So I leave you with this slightly longer answer than the one that I stated at the beginning. “Is economics useful for public policy?" Of course - as long as we begin our policy advice with "It depends".

\section{$\underline{\text { References }}$}

Adhikari, Bibek, and James Alm. 2016. Evaluating the economic effects of flat tax reforms using synthetic control methods. Southern Economic Journal 83 (2): 437-463.

Akerlof, George A., and Rachel E. Kranton, R. E. (2010). Identity Economics: How Our Identity Shape Our Work, Wages and Well-being. Princeton, NJ: Princeton University Press.

Allingham, Michael G., and Agnar Sandmo. 1972. Income tax evasion: A theoretical analysis. Journal of Public Economics 1 (3-4): 323-338.

Alm, James. 1988. Noncompliance and payroll taxation in Jamaica. The Journal of Developing Areas 22 (4): 477-495.

Alm, James. 2006. Assessing Puerto Rico's fiscal policies. In The Economy of Puerto Rico, edited by Susan M. Collins, Barry P. Bosworth, and Miguel A. Soto-Class. Washington, D.C.: The Brookings Institution and The Center for the New Economy, 319-375.

Alm, James. 2012. Measuring, explaining, and controlling tax evasion: Lessons from theory, field studies, and experiments. International Tax and Public Finance 19 (1): 54-77.

Alm, James. 2016. Is Haig-Simons dead? Tulane University Department of Economics Working Paper. New Orleans, LA.

Alm, James, M. V. Lee Badgett, and Leslie A. Whittington. 2000. Wedding bell blues: The income tax consequences of legalizing same-sex marriage. National Tax Journal 53 (2): 201-214. 
Alm, James, Roy Bahl, and Matthew N. Murray. 1990. Tax structure and tax compliance. The Review of Economics and Statistics 72 (4): 603-613.

Alm, James, Roy Bahl, and Matthew N. Murray. 1991. Tax base erosion in developing countries. Economic Development and Cultural Change 39 (4): 849-872.

Alm, James, Kim M. Bloomquist, and Michael McKee. 2016. When you know your neighbor pays taxes: Information, peer effects, and tax compliance. Fiscal Studies forthcoming.

Alm, James, David Bruner, and Michael McKee. 2016. Honesty and dishonesty in taxpayer communications in an enforcement regime. Journal of Economic Psychology forthcoming.

Alm, James, Robert D. Buschman, and David. L. Sjoquist. 2011. Rethinking local government reliance on the property tax. Regional Science and Urban Economics 41 (4): 320-331.

Alm, James, Jeremy Clark, and Kara Leibel. 2016. Enforcement, socio-economic diversity, and tax filing compliance in the United States. Southern Economic Journal 82 (3): 725-747.

Alm, James, Stacy Dickert-Conlin, and Leslie A. Whittington. 1999. The marriage tax. The Journal of Economic Perspectives 13 (3): 193-204.

Alm, James, and Grant Driessen. 2016. Expanding the Louisiana sales tax to services. In Reforming Louisiana's Tax System, edited by James A. Richardson, Steven M. Sheffrin, and James Alm. Baton Rouge, LA: Louisiana State University Press, forthcoming.

Alm, James, Betty R. Jackson, and Michael McKee 1992. Estimating the determinants of taxpayer compliance with experimental data. National Tax Journal 45 (1): 107-114.

Alm, James, Betty R. Jackson, and Michael McKee. 1993. Fiscal exchange, collective decision institutions, and tax compliance. Journal of Economic Behavior and Organization 22 (4): 285-303.

Alm, James, Betty R. Jackson, and Michael McKee. 2009. Getting the word out: Increased enforcement, audit information dissemination, and compliance behavior. Journal of Public Economics 93 (3-4): 60-84.

Alm, James, Fitzroy Lee, and Sally Wallace. 2005. How fair? Federal income taxation and the distribution of income, 1978 to 1998. Journal of Policy Analysis and Management 24 (1): $5-22$.

Alm, James, and J. Sebastian Leguizamon. 2015. Whither the marriage tax? National Tax Journal 68 (2): 251-280.

Alm, James, J. Sebastian Leguizamon, and Susane Leguizamon. 2014. Revisiting the income tax consequences of legalizing same-sex marriage. Journal of Policy Analysis and Management 33 (2): 263-289.

Alm, James, and Chandler McClellan. 2012. Tax morale and tax compliance from the firm's perspective. Kyklos 65 (1): 1-17

Alm, James, Jorge Martinez-Vazquez, and Chandler McClellan. 2016. Corruption and firm tax evasion. Journal of Economic Behavior and Organization 124: 146-163.

Alm, James, Carlos Ortiz, and Diana Rocha. 2016. Using "messages" to improve payroll tax compliance in Colombia. Tulane University Department of Economics Working Paper. New Orleans, LA.

Alm, James, and Janet Rogers. 2011. Do state fiscal policies affect economic growth? Public Finance Review 39 (4): 483-526.

Alm, James, and Edward Sennoga. 2010. Mobility, competition, and the distributional effects of tax evasion. National Tax Journal 63 (4, Part 2): 1055-1084. 
Alm, James, and Jay Shimshack. 2014. Environmental enforcement and compliance: Lessons from pollution, safety, and tax settings. Foundations and Trends in Microeconomics 10 (4): 209-274.

Alm, James, and David L. Sjoquist. 2014. State government revenue recovery from the "Great Recession". State and Local Government Review 46 (3): 164-172.

Alm, James, and Sally Wallace. 2007. Are Jamaica's direct taxes on labor "fair"? Public Finance Review 35 (1): 83-102.

Alm, James, and Mohammed Yunus. 2009. Spatiality and persistence in U.S. individual income tax compliance. National Tax Journal 62 (1): 101-124.

Alston, Richard M., James R. Kearl, and Michael B. Vaughan. 1992. Is there a consensus among economists in the 1990s? The American Economic Review 82 (2): 203-209.

Andreoni, James, Brian Erard, and Jonathan Feinstein. 1998. Tax compliance. The Journal of Economic Literature 36 (2): 818-860.

Auerbach, Alan J., and Joel Slemrod. 1997. The economic effects of the Tax Reform Act of 1986. The Journal of Economic Literature 35 (2): 589-632.

Auerbach, Alan J. and James R. Hines, Jr. 2002. Taxation and economic efficiency. In Handbook of Public Economics, Vol. 3 (Chapter 21), edited by Alan J. Auerbach and Martin Feldstein. Amsterdam, London, and New York: Elsevier B.V. North Holland Publishers, 1347-1421.

Bakija, Jon, and C. Eugene Steuerle. 1991. Individual income taxation since 1948. National Tax Journal 44 (4): 451-475.

Bird, Richard M., and Barbara Diane Miller. 1989. The incidence of indirect taxes on lowincome households in Jamaica. Economic Development and Cultural Change 37 (2): 393-409.

Bittker, Boris I. 1975. Federal income taxation and the family. Stanford Law Review 27 (4): 1388-1463.

Carillo, Paul, Dina Pomeranz, and Monica Singhal. 2014. Dodging the taxman: Firm misreporting and limits to tax enforcement. Harvard Business School Working Paper 15026. Cambridge, MA.

Congressional Budget Office. 1997. For Better or For Worse: Marriage and the Federal Income Tax. Washington, D.C.: Congress of the United States.

Diamond, Peter, and Emmanuel Saez. 2011. The case for a progressive tax: From basic research to policy recommendations. The Journal of Economic Perspectives 25 (4): 165-190.

Frey, Bruno S., Victor Ginsburgh, Pierre Pestieau, Werner W. Pommerehne, and Friedrich Schneider. 1983. Consensus, dissension and ideology among economists in various European countries and in the United States. European Economic Review 23: 59-69.

Frey, Bruno S., and Reiner Eichenberger. 1992. Economics and economists: A European perspective. The American Economic Review 82 (2): 16-20.

Fuchs, Victor R., Alan B. Krueger, and James M. Poterba. 1998. Economists' views about parameters, values, and policies. The Journal of Economic Literature 36 (3): 1387-1425.

Gale, William G., Aaron Krupkin, and Kim Rueben, 2015. The relationship between taxes and growth at the state level: New evidence. National Tax Journal 68 (4): 919-942.

Gemmell, Norman, Richard Kneller, and Ismael Sanz. 2014. The growth effects of tax rates in the OECD. Canadian Journal of Economics 47 (4): 1217-1255.

Haig, Robert M. 1921. The concept of income - Economic and legal aspects. In The Federal Income Tax, edited by Robert M. Haig. New York, NY: Columbia University Press, 1-28. 
Hallsworth, Michael. 2014. The use of field experiments to increase tax compliance. Oxford Review of Economic Policy 30 (4): 658-679.

Hashimzade, Nigar, Gareth D. Myles, and Binh Tran-Nam. 2013. Applications of behavioural economics to tax evasion. Journal of Economic Surveys 27 (5): 941-977,

Johns, Andrew, and Joel Slemrod. 2010. The distribution of income tax noncompliance. National Tax Journal 63 (3): 397-418.

Johnson, Anna L., and Steven M. Sheffrin. 2016. The success of SNAP (food stamps) and the desirability of taxing food. In Reforming Louisiana's Tax System, edited by James A. Richardson, Steven M. Sheffrin, and James Alm. Baton Rouge, LA: Louisiana State University Press, forthcoming.

Kaplow, Louis. 1989. Horizontal equity: Measures in search of a principle. National Tax Journal 36 (4): 139-154.

Kearl, James R., Clayne L. Pope, Gordon C. Whiting, and Larry T. Wimmer. 1993. A confusion of economists? The American Economic Review 69 (2): 28-37.

Keynes, John Maynard. 1936. The General Theory of Employment, Interest, and Money. London, UK: Palgrave Macmillan Publishing.

Lutz, Byron, Raven Molloy, and Hui Shan. 2011. The housing crisis and state and local government tax revenue: Five channels. Regional Science and Urban Economics 41 (4): 306-319.

Mankiw, N. Gregory, Matthew C. Weinzierl, and Danny Yagan. 2009. Optimal taxation in theory and practice. The Journal of Economic Perspectives 23 (4): 147-174.

Pechman, Joseph A. 1985. Who Paid the Taxes, 1966-1985? Washington, D.C.: The Brookings Institution.

Pechman, Joseph A., and Benjamin A. Okner. 1974. Who Bears the Tax Burden? Washington, D.C.: The Brookings Institution.

Reed, W. Robert. 2009. The determinants of U.S. state economic growth: A less extreme bounds analysis. Economic Inquiry 47 (4): 685-700.

Richardson, James A., Steven M. Sheffrin, and James Alm (eds.). 2016. Reforming Louisiana's Tax System. Baton Rouge, LA: Louisiana State University Press, forthcoming.

Saez, Emmanuel, Joel Slemrod, and Seth Giertz. 2009. The elasticity of taxable income with respect to marginal tax rates: A critical review. The Journal of Economic Literature 50 (1): 3-50.

Sandmo, Agnar. 2012. An evasive topic: Theorizing about the hidden economy. International Tax and Public Finance 19 (1): 5-24.

Schanz, Georg von. 1896. Der einkommensbegriff und die einkommensteuergesetze [Income realized and the income tax law]. FinanzArchiv 13 (1): 1-87.

Sheffrin, Steven M. 2013. Tax Fairness and Folk Justice. New York, NY: Cambridge University Press.

Simons, Henry. 1938. Personal Income Taxation: The Definition of Income as a Problem of Fiscal Policy. Chicago, IL: University of Chicago Press.

Slemrod, Joel. 1995. Professional opinions about tax policy: 1994 and 1934. National Tax Journal 48 (1): 121-147.

Slemrod, Joel, Marsha Blumenthal, and Charles C. Christian. 2001. Taxpayer response to an increased probability of audit: Evidence from a controlled experiment in Minnesota. Journal of Public Economics 79: 455-483. 
Slemrod, Joel, and Shlomo Yitzhaki. 2002. Tax avoidance, evasion, and administration. In Handbook of Public Economics, Volume 4 (Chapter 22), edited by Alan J. Auerbach and Martin Feldstein. Amsterdam, London, and New York: Elsevier B.V. North Holland Publishers, 1423-1470.

Williamson, John (1990). "What Washington Means by Policy Reform”. In Latin American Readjustment: How Much Has Happened, edited by John Williamson. Washington, D.C.: Peterson Institute for International Economics, Chapter 2.

\section{Notes}

${ }^{1}$ Department of Economics, Tulane University, 6823 St. Charles Avenue, 208 Tilton Hall, New Orleans, LA, 70118. Phone: +1 504862 8344. Fax: +1 504865 5869. Email: jalm@ tulane.edu. This paper was prepared for the 2016 Southern Economic Association Annual Conference, held in Washington, D.C. in November 2016, for my Presidential Address. I am grateful to many people for extraordinarily helpful comments on earlier versions of this paper: Roy Bahl, Michael Bernstein, Richard Bird, Arthur Brooks, Michael Darden, Janet Johnson, Steven Sheffrin, Jay Shimshack, and David Sjoquist. They did not always agree with my conclusions, but they were invariably gracious and generous in their comments, all of which have immeasurably improved the clarity of my arguments. I am also grateful to Ali Enami for help in compiling some of the data used in the paper.

${ }^{2}$ See Alston, Kearl, and Vaughan (1992) and Kearl et al. (1993) for examples for United States economists and Frey et al. (1983) and Frey and Eichenberger (1992) for examples for European economists. For more recent examples, see the IGM Experts Panel at http://www.igmchicago.org/igm-economic-experts-panel .

${ }^{3}$ See Slemrod (1995) and Fuchs, Krueger, and Poterba (1998). As a recent and benign example, the Fiscal Affairs Division of the International Monetary Fund has started publishing "How To" notes, which attempt to distill the varied lessons of fiscal policy into "best practices", available at http://www.imf.org/en/Publications/SPROLLs/How-To-Notes

${ }^{4}$ Indeed, even the standard health advice "Floss your teeth daily" has come into question. See http://bigstory.ap.org/article/f7e66079d9ba4b4985d7af350619a9e3/medical-benefits-dentalfloss-unproven .

${ }^{5}$ In this context, it is of course necessary to quote John Maynard Keynes (1936, 383-384) in his The General Theory of Employment, Interest, and Money:

"The ideas of economists and political philosophers, both when they are right and when they are wrong, are more powerful than is commonly understood. Indeed the world is ruled by little else. Practical men, who believe themselves to be quite exempt from any intellectual influence, are usually the slaves of some defunct economist. Madmen in authority, who hear voices in the air, are distilling their frenzy from some academic scribbler of a few years back."

${ }^{6}$ Another implicit assumption is that labor market adjustments are not considered; that is, the analysis is partial equilibrium, not general equilibrium. For example, progressive tax rates may drive workers to the informal sector where they pay no taxes. See Alm and Sennoga (2010) for an analysis of these general equilibrium effects. A more explicit assumption is that the actual incidence of any tax is known, and this assumption is also a questionable one in many settings. 7 "Personal services" include: scenic and sightseeing transportation services and support activities for transportation; veterinary services; cable and other subscription services; 
performing arts; promotional services for performing arts and sports and public figures; independent artists, writers, and performers; museum, heritage, zoo, and recreational services; personal care services; and other personal services. "All services" include: transit and ground passenger transportation services; couriers and messenger services; accounting, tax preparation, bookkeeping, and payroll services; architectural, engineering, and related services; photographic services; all other miscellaneous professional, scientific, and technical services; data processinghosting-ISP-web search portals; other information services; and insurance-related support services.

${ }^{8}$ For useful surveys of this large and still growing literature, see Andreoni, Erard, and Feinstein (1998), Slemrod and Yitzhaki (2002), Alm (2012), and Sandmo (2012).

${ }^{9}$ See Alm, Bahl, and Murray (1990), Alm, Jackson, and McKee (1992), Alm and Yunus (2009), and Alm, Clark, and Leibel (2016).

${ }^{10}$ For example, see Hashimzade, Myles, and Tran-Nam (2013).

${ }^{11}$ See Alm and McClellan (2012), Alm and Shimshack (2014), and Alm, Martinez-Vazquez, and McClellan (2016).

${ }^{12}$ See the many studies listed on the IRS "tax gap" website at https://www.irs.gov/uac/the-taxgap. Of most relevance, the IRS has estimated the "Net Misreporting Percentage" (NMP) for different sources of income, which measures the unreported (or "misreported") income as a fraction of the estimated "true" income. The NMP for income "subject to little or no information reporting" (e.g., nonfarm proprietor income, rents and royalties, farm income, Form 4797 income, and adjustments) exceeds 50 percent, and is the main driver of the "tax gap", defined as the difference between that taxes that should be paid and taxes that are actually paid. In contrast, the NMP for income "subject to substantial information reporting and withholding (e.g., wages and salaries) is a negligible 1 percent. Even income "subject to some information reporting (e.g., deductions, exemptions, partnerships and S-corporation income, capital gains, and alimony income) has an estimated NMP of only 11 percent.

${ }^{13}$ Even here, however, the evidence is a bit more nuanced. A recent field experiment by Carillo, Pomeranz, and Singhal (2014) found that firms in Ecuador filed amended tax returns that increased their reporting of revenue when told by the tax administration of "discrepancies" between their reports and third-party reports. However, these same firms also increased their claims of costs on their amended returns because their costs were not subject to third-party reports. The net effect of both adjustments was to leave taxable income virtually unchanged.

14 The empirical literature on behavioral responses to taxation is enormous. See Auerbach and Slemrod (1997) for a comprehensive, if now somewhat dated, review and Saez, Slemrod, and Giertz (2009) for a narrower, if more recent, review.

${ }^{15}$ For two illustrative reviews and analyses, see Reed (2009) and Gemmell, Kneller, and Sanz (2014). These are only two examples from a vast empirical literature that uses cross section, time series, and panel studies of states and countries.

${ }^{16}$ See Laffer's website at http://www.laffercenter.com/, especially the link to "supply-side economics" at http://www.laffercenter.com/supply-side-economics/.

${ }^{17}$ See the Nelson A. Rockefeller Institute of Government website at http://www.rockinst.org/ . See especially the link to state revenue reports at http://www.rockinst.org/government_finance/state_revenue_reports.aspx.

${ }^{18}$ See Schanz (1896), Haig (1921), and Simons (1938) for detailed discussions.

${ }^{19}$ See Auerbach and Hines (2002) for a detailed discussion of efficient taxation. 
${ }^{20}$ For the details of our tax policy recommendations, see Richardson, Sheffrin, and Alm (2016). Also, we were all appointed by Louisiana Governor John Bell Edwards to serve on a "Task Force on Structural Change in Budget and Tax Policy", whose recommendations are now available online at www.revenue.louisiana.gov/taskforce.

${ }^{21}$ See Alm (2016) for a more detailed discussion of these issues. 